\title{
“Öğrenci Törless’in Bunalımları”: 20. Yüzyıl Başındaki Eğitim Sorunsalı ve Hitler'in Ayak Sesleri ${ }^{1}$
}

\author{
Fatma Öztürk Dağabakan (iD), Erzurum - Recep Bodur (iD, Amasya \\ https://dx.doi.org/10.37583/diyalog.958465
}

$\ddot{O} z$

Robert Musil (1880-1942), modern roman türünün oluşumuna ve gelişimine önemli katkıları olan, 20. yüzyılda Avusturya Edebiyatı'nın en önde gelen yazarlarındandır. Eserlerinde 20. yüzyıl başındaki dönüşümü ve bu dönüşümün birey ve toplum üzerindeki etkilerini konu edinmektedir. 1906 y1lında yayınlanan ilk romanı Öğrenci Törless'in Bunalımlarl'nda da içinde yaşanılan dönemin ve sınıf farkının eğitime yansıması, eğitim ve yatılı okul sisteminin insanlıkla bağdaşmayan yanları, buna bağlı olarak genç ve yaratıcı bireylerin sorunları ve otonom gelişimlerinin engellenmesi gibi konular ele alınmıştır. Ayrıca eserde yüzyıl başındaki dönüşüme paralel olarak toplumda yavaş yavaş hissedilmeye başlanan faşizmin ayak sesleri konu edinilmiştir. Bu çalışmada, 20. yüzyıl başındaki modernist dönüşümün eğitim ve okul sistemi üzerindeki izleri gün ışığına çıkarılmaya ve Hitler ekolünün alttan alta gelişi gösterilmeye çalışılmıştır. Bu vesileyle çalışmamızın özellikle o dönemdeki eğitim sorunsalı ve Hitler zihniyetinin doğuşu üzerine yapılacak çalışmalara bir rehber olması amaçlanmıştır. Araştırma sürecinde metne bağlı, yorum bilimine dayalı inceleme yöntemlerine ve yer yer de metinlerarasıllk yöntemine başvurulmuştur.

Anahtar Sözcükler: Robert Musil, Eğitim Sorunsal, Birey, Hitler Ekolü.

\begin{abstract}
“The Confusions of Young Törless": The Education Problem at the Beginning of the 20th Century and Hitler's Footsteps
\end{abstract}

Robert Musil (1880-1942) is one of the foremost writers of Austrian literature in the 20th century, who made important contributions to the formation and development of the modern novel genre. His works deal with the transformation of the early 20th century and the effects of this transformation on individuals and society. In his first novel, The Confusions of Young Törless, published in 1906, the reflection of the period and class difference on education, the incompatible aspects of the education and boarding school system, the problems of young and correspondingly creative individuals and their autonomous development are discussed. In addition, in parallel with the transformation at the beginning of the century, the footsteps of fascism, which began to be felt in the society, are the subject of the work. The study attempted to bring to light the traces of the modernist transformation of the early 20th century on the education and school system and to show the bottom-up of the Hitler ecole. On this occasion, our study is aimed to be a guide for the studies to be carried out on the education-school problem of that period and

Einsendedatum: 02.02.2021

Freigabe zur Veröffentlichung: 30.06.2021

${ }^{1} \mathrm{Bu}$ çalışma, Recep Bodur'un Prof. Dr. Fatma Öztürk Dağabakan danışmanlığında hazırlamakta olduğu

'Hermann Hesse’nin “Çarklar Arasında”, Robert Musil'in “Öğrenci Törless’in Bunalımları” ve Ödön von Horvath'ın “Allahsız Gençlik” Adlı Eserlerinde Eğitim ve Toplumun Birey Üzerindeki Etkileri’ adlı doktora tezinden üretilmiştir. 
the birth of the Hitler mentality. During the research process, werkimmanent, hermeneutic methods and sometimes intertextuality method were used.

Keywords: Robert Musil, Education Problem, Individual, Hitler Ecole. 


\section{EXTENDED ABSTRACT}

This study focuses on the crisis of the education-school system at the beginning of the 20th centuries and the emergence of an emerging fascism in the work "The Confusions of Young Törless" of Robert Musil. The study generally consists of two parts. In the first part, the destructive effects of authoritarian education on young people are presented. In the second part, the birth of the Hitler ideology (fascism), which is a black stain on the name of human history, is tried to be shown in the eyes of the students under the roof of the school, which is a social institution.

Robert Musil attends military schools in Eisenstadt and Moravia-Weisskirchen for 5 years as a child. His experiences here - authoritarian education and discipline turn into a traumatic state. The education here leaves little space for young people to develop their own feelings and thoughts, especially during the self-seeking phase, and condemns them to be guided by others. This causes young people to suppress their emotions and to close the doors of their inner (emotional) worlds. Over time, these cause various forms of crossing borders and negativities.

The boarding school $\mathrm{W}$. which is seen as the transition point for social position among the elite in the novel, provides a military-style education that cannot keep up with the times. Here, particularly sensitive and creative students find it very difficult to rely on the strict school system that puts their personalities under pressure and is unable to develop their abilities. Most students commit suicide in desperation, not overcoming their crisis.

Students who question and develop themselves are not desired in this school. Obedience is the only common rule. Teachers who see themselves as the authority of science are certain to say, at this point all that needs to be done is to believe what the teacher says. Since these people are incapable of questioning their mental and social conditions creatively, they want students to be educated in this way, too. In the work, teachers are depicted as people with narrow horizons.

This novel also brings to light various socio-cultural and political aspects reflected in the contradictory spirit of the time. In this context, power and violence are among the prominent aspects of the period when the novel was written. What happened at school, and especially those narrated through the characters Reiting and Beineberg, are seen as a copy of a dictatorial regime. Looking at the dictatorial characters of the class, Musil creates a structure based on power and violence through sexuality. Contrary to the usual scheme of school novels, problems in this novel are not created by educators, but by students. It's not just boarding school pranks, teenage depressions, and under-rated homosexual relationships, but also sadism, the choice of the victim, which symbolizes the aimlessly tortured weak. Therefore, in the work, there is also an image of the social power balances reflected in the literature.

The famous blood-red room in the novel serves first as the refuge of the three main characters, Törless, Reiting and Beineberg, and later as the torture chamber for Basini. This room is located under the roof of the school, a representative of public 
morals and norms. In fact, this loft emerges as a blind spot of secretly isolated and dangerously distorted rules. The depiction of this place already shows the abnormality and barbarism that will be developed during the action.

Reiting and Beineberg, who dominate the class, sovereignly exercise their power over the class and another character, Basini. Through them, Musil shows the burgeoning foundations of Nazi Germany in this work. These two characters create their own style, creating the Hitler ecole (school) and the methodology of future concentration camps. Musil predicts that fascist ideology began to spread in the pre-Hitler era and this spread turned into a malicious one. This novel is considered a prophecy of Hitler's dictatorship and genocide, based on the author's comments on his own work. 


\section{Giriş}

Robert Musil, 20. yüzyılın en önemli romancılarından biridir. Dünya edebiyatının başyapıtlarından biri olan Der Mann ohne Eigenschaften (1930-1943) adlı büyük eseriyle modern düzyazının ve modernist roman türünün en büyük ustalarından biri olarak kabul edilmektedir. Musil, her ne kadar Der Mann ohne Eigenschaften (Niteliksiz Adam) eseriyle büyük kitlelere ulaşsa da yüzyıl başındaki değişimi ve dönüşümü, ilk olarak Die Verwirrungen des Zöglings Törleß (Öğrenci Törless'in Bunalımları) adlı eserinde ortaya koymuştur. Musil'in 26 yaşındayken yayınlanan ilk romanı Die Verwirrungen des Zöglings Törleß, Avusturya Edebiyatı'nın en önemli yatılı okul romanları arasında yerini almıştır.

Die Verwirrungen des Zöglings Törleß çok yönlü bir romandır. Genel anlamda Viyana modernizm dönemine özgü birçok bireysel, toplumsal, felsefi, psikolojik ve epistemolojik konuları içerse de, esasen öğrenci Törless'in gelişiminin kısa bir evresini, dönemin eğitim ve okul sisteminin birey üzerindeki yıkıcı etkilerini ve doğmakta olan yeni bir ideolojiyi konu edinmektedir. Bu bakımdan eser, bir yandan genç "Törless'in bireyleşme (Individuation) sürecinin biyografik bir hikâyesi olduğu için, bir bakıma oluşum romanına" (Bildungsroman) (Aytaç 2005: 263) benzer, diğer yandan da genel olarak okul, öğrenci ve öğretmenler konu edildiği için "okul romanı" (Schulroman) (Asutay 2020: 84) özelliği taşır.

Eğitim ve okul sisteminin içinde bulunduğu kriz, 20. yüzyılın başında bazı edebi metinlere yansımıştır. Bu metinlerde özellikle duyarlı ve yaratıcı öğrenciler, kişiliklerini baskı altında tutan ve yeteneklerini geliştiremedikleri katı okul sistemine dayanmakta çok zorlanmışlardır. Çoğu öğrenci çaresizlik içinde bunalımları aşamayarak intiharı seçmiştir (Asutay 2020: 84). Gençlerin trajik kaderleri, Hermann Hesse (Unterm Rad1906), Rainer Maria Rilke (Die Turnstunde-1902) gibi bazı yazarlar tarafindan kaleme alınmıştır. Die Verwirrungen des Zöglings Törleß eserinde de katı askeri eğitim sisteminden ve "estetik, fikri tabiatıyla kurumun mevcut kolektif gerçekliği arasındaki çekişme"den (Aytaç 2005: 263) bitkin düşen bir öğrencinin hikâyesi yer almaktadır. Kendisine popüler asker romanları arasında yer bulan bu eser, popüler asker edebiyatı (Kadettenliteratur) $^{2}$ çerçevesinde okul romanının özel bir türü olarak incelenecektir.

Popüler asker edebiyatı denildiğinde akla genelde "eleştirel-suçlayıcı" bir zihniyetle ortaya konan eserler gelmektedir, ancak bunların içerisinde "müdafiyüceltici” (Johann 2003: 228) eserler de mevcuttur. Bu eserler, askeri eğitimi ve kurumları yüceltir ve böylece vatanseverliği, asker olmayı ve vatanları için canlarını feda etmeyi mistik bir havaya büründürür. Çoğu genç insan bu tarz kitaplarla ve eğitimlerle askerlik görevine teşvik edilir. Bu tür edebiyatın, Wilhelm döneminde toplumun militaristleşmesi ile bağlantılı olduğu varsayımı, edebiyat ve toplum

\footnotetext{
${ }^{2}$ Popüler asker edebiyat1, Wilhelm döneminden Nasyonal Sosyalizm (1895-939) dönemine kadar uzanan gençlik edebiyatının bir türüdür (Steinlein 2013: 109). İçerisinde askeri okulların ve askeri bir eğitim şeklinin anlatılmasının yanında, eğitimin ve genç insanların o zaman içinde bulundukları kriz de yansitilmaktadır (Minder 1962: 73).
} 
arasındaki ilişkinin araştırılmasında önemli rol oynamaktadır. Bu perspektiften genel itibariyle popüler asker edebiyatının doğrudan ya da dolaylı olarak "diktatörlüğün ve dünya savaşının barbarlığı" (Johann 2003: 71) ile bir dereceye kadar ilintili olduğu varsayılabilir.

\section{Öğrenci Törless'in Bunalımları: Yüzyıl Başındaki Eğitim Krizi}

Romanın başkahramanı Törless, Avusturya-Macaristan İmparatorluğu'na bağlı askeri bir okulda eğitim gören genç bir öğrencidir ve çok fazla arkadaşa sahip değildir. Genelde Reiting ve Beineberg adındaki iki arkadaşıyla takılmaktadır. Törless her ne kadar başkahraman olsa da bu iki arkadaşın gölgesinde kalmaktadır. Tüm olaylarda Reiting ve Beineberg ön plana çıkmaktadır. Aslında üst akıl odur, ancak olayları yönlendirme anlamında çok bir etkisi yoktur. Bir gün Basini adındaki bir öğrencinin hırsızlık yaptığını keşfederler ve bunu kullanarak ona şantaj ve işkence yapmaya, alçak deneyleri için ondan istifade etmeye başlarlar. Bunları, kırmızı oda diye adlandırdıkları okulun çatı katında kemerle dövme, cinsel taciz gibi eylemler adı altında gerçekleştirirler. Üç arkadaşın kendi içlerinde farklı tarzları vardır. Psikolojik ve felsefi bunalımlarla, ayrıca cinsel fantezilerle boğuşan Törless olaylara ilk başlarda ses çıkarmaz, olanları geriden gözlemler ve her şeye göz yumar. Reiting, insanları manipule eden, kitle ruhundan çok iyi anlayan modern bir diktatördür. Usdışı düşüncelere inanan ve kendisine mistik Uzakdoğu felsefesini rehber edinen Beineberg ise mizacindaki soğukkanlılıkla ortamı tiranlaştırmaktadır.

Bir tatil gününde herkes evine gittiğinde Törless ve Basini arasında bir yakınlaşma olur. Basini eril özellikleri tam oturmamış feminen bir yapıya sahiptir, ayrıca mazoşisttir. Törless'in de cinselliğinin daha tam şekillenmemiş olması yakınlaşmalarını kolaylaştırmıştır. Reiting ve Beineberg'in Basini’ye karşı zulmü gün geçtikçe öyle vahşi bir hale dönüşür ki, Törless artık olanlara dayanamaz ve Basine’ye her şeyi müdüre anlatmasını salık verir. Tüm olanlar ortaya çıkınca, Törless okuldan kaçar ancak bulunup geri getirilir. Törless'in ailesi de onu okuldan alır.

Die Verwirrungen des Zöglings Törleß romanındaki hikâyenin geçtiği yer, askeri bir okuldur. Musil, bundan doğrudan bahsetmese de romanın bazı yerlerinde buna dair belirgin imalarda bulunmaktadır. Örneğin bunun en açık göstergesi, Törless'in ebeveyninin ayrılma sahnesinde, öğrencilerin genelde yanlarında taşıyorlarmış gibi bir görüntü çizdikleri meçlerdir: "Arkadaşları bellerindeki meçlere çekidüzen vererek, çizmelerinin topuklarını birbirine vurup vaziyet aldılar" (Musil 2014: 29).

W.'deki yatılı okul, elit bir okuldur, yani "ülkenin en seçkin ailelerinin çocukları"nın (Musil 2014: 16) eğitildiği askeri bir eğitim kurumudur. Böyle okullar genellikle bir toplumdaki eşitsizliğin çoğalmasını teşvik etme eğilimindedir, mevcut normları ve toplumsal değerleri korur. Musil, "sermaye çıkarlarını" genel olarak eğitimin gizli özelliği olarak anlar ve toplumsal işlevini "»mülkiyet ile eğitim« ya da »ekonomi ile insan« arasındaki boşluğun olumlu anlamda üstesinden gelmede değil, [...] bilakis bu ayrımın sertleştirilmesinde" (Willemsen 1985: 37) görür. Keza bu görüş 
onun romanında açıkça ortaya konmaktadır. Ana kahraman Törless, ait olduğu sınıfın oldukça farkındadır. Arkadaşı Basini'nin hırsızlıktan sonra okulda kalmasına karşı çıktığında, onun ve arkadaşlarının aynı sosyal sınıfa ait olduklarını ve bundan dolayı yatılı okulda bir arada eğitildiklerini vurgular: "Biz hepimiz de aynı kesimden geldiğimiz için, bir arada eğitilip yetiştiriliyoruz" (Musil 2014: 84).

Yatılı okul, açıkça seçkin sınıf arasında "sosyal konumlanma için geçiş yeri" (Johann 2003: 263) olarak görülmektedir. Bu okulda okumak, bireyin geleceğinin anahtarıdır. Güncelliğini hiçbir devirde yitirmeyen bu olgu, esere şu şekilde yansimaktadir:

Okulda ülkenin en seçkin ailelerin çocukları eğitim ve öğrenim görüyor, burayı bitirdikten sonra ya üniversiteye gidiyor, ya askerlik mesleğine atıllyor ya da devlet hizmetinde çalışmaya başlıyor, söz konusu durumlarda, ayrıca yüksek çevrelere girip çıkabilme bakımından W.'deki okulda okumuş olmak ayrı bir üstünlük sağlıyordu. (Musil 2014: 24-25)

Musil, her ne kadar bu sınıf ayrımının farkında olsa da yine de eğitim kurumu olarak görmediği askeri okulun bu hegemonyasını beğenmez ve onu her zaman eleştirir. Askeri okula hem geleceği garanti altına alınsın hem de adam olsun diye gönderilmiştir (Musil 2018: 298). Ailesi tarafından çok şımartılan Musil, şiddete ve sertliğe meyilli bir çocuktur ve bunun da farkındadır. Dolayısıyla askeri okula başlama serüveni ilk başlarda iki taraf için de -kendisi ve ebeveynleri- çok zor olmamıştır. 1937-1941 yılları arasındaki günlüğüne şu notları düşer: "Ben kolay terbiye edilemeyen bir çocuktum, zorla bana hiçbir şey kabul ettiremiyorlardı. Bu nedenle günü geldiğinde evden ayrılmam ve askeri okula gönderilmem konusunda kolay anlaşmıştık" (Musil 2018: 359).

Musil, toplam beş y1l boyunca Eisenstadt (1892-1894) ve MoravyaWeisskirchen'deki (1894-1897) askeri okullara gitmiştir. Okulda başarılı olmasına rağmen, o zamanki deneyimleri adeta travmatik bir hale dönüşmüştür. Askeri okul yurdunda kalma, bireylere o zamanlar büyük bir saygınlık kazandırsa da ve bir ayrıcalık olarak görülse de, okul aslında vahim bir durum içerisindedir. Yıllar sonra dahi Musil günlügünde bundan yakınmaktadır. Bu askeri okullara karşı nefretini gizlemez ve onlardan son derece olumsuz bir şekilde bahseder:

\footnotetext{
Askeri lisedeki derslerin dışında bizlere pek değer vermediklerini davranışlarından seziyordum. Bütün gün baş̧̧avuşlarla eğitim çavuşları başımızdaydı. Üzerimize giydirdikleri üniformalar ve postallar tuhaftı. Merasim üniforması bile sirtıma uymuyordu, görünümü gülünçtü. Hapiste yatanlardan daha tuhaf. Yıkanma olanakları kısttl. Tuvaletler de. O günlerden kalma bir fotoğraf Eisenstadt'taki büyük çayırda jimnastik yapan yatılı öğrencileri gösteriyor. Annemle babam duruma niçin karşı çıkmamıştı? Aradan y1llar geçtikten sonra bile anlamıyorum. Hay Allah! (Musil 2018: 325)
}

Romandaki okuldan, Musil'in günlüğünde anlattığı askeri eğitime dair çok fazla bilgi elde edilemeyebilir. Ancak yine de bu okulun istenilen eğitim ve öğretimi sunmadığ aşikardır. Romanın başında, çevre ve insanlar melankolik ve hüzünlü olarak tasvir edilir. Bu tasvir, cansız ve mekanik bir eğitimin olduğunu gösterir: “[...], nedense eşya 
ve insanlarda bir umursamazlık, bir ölgünlük, kukla tiyatrosundan alınıp getirilmişler gibi bir mekaniklik göze çarpıyordu" (Musil 2014: 15).

Otoriter eğitim ve disiplin altına alma, kuklacıların kukla tiyatrosundaki faaliyetleri ile olan ilişkilerini çağrıştırmaktadır. Eğitimin uyarlanabilir doğası, gençlere özellikle kendi kendilerini arama aşamasında, kendi duygu ve düşüncelerini geliştirmeleri için çok az alan bırakmakta ve onları başkaları tarafından yönlendirilmeye mahkûm etmektedir (Grossmann 1988: 92). Böyle bir eğitim, öğrencilerin iç dünyasını yok sayar, dolayısıyla öğrenciler "duygusal dünyaya kapılarını kapatırlar ve içgüdü tatminlerini gizliliğe sürüklerler” (Tiefenbacher 1982: 158). Törless'in iç dünyasındaki açlık sadece yaşamın değil, aynı zamanda okuldaki mekanik eğitimin bir sonucudur. Hassas ruhlu Törless'e göre sınıf arkadaşları "mekanik bir düzenek” (Musil 2014: 146) gibidir. Törless bunu uyuyan arkadaşlarında bile hissetmektedir: "[...] mekanik bir düzenek gibi bir inip, bir kalkan düzenli, biri ötekisi gibi rahat, biri ötekisi gibi güvenli bir sürü soluyuştan biriydi” (Musil 2014: 146).

$\mathrm{Bu}$ okulun dikkat çeken olumsuz ve eksik yanlarından biri de, özellikle edebiyata değer verilmemesi ve edebiyatın küçümsenmesidir. Musil'e göre edebiyat, genç insanların gelişimi için "değeri ölçülemeyecek" (Musil 2014: 24) cinstendir. Musil gibi, Moravya-Weisskirchen'deki askeri ortaokulda okuyan ve aynı acıları yaşayan Rilke’ye göre, gençler edebiyatta “edebi bir alternatif yaşam” (Issler 1972: 7) yaratabilirler.

Çünkü gençleri ellerinden tutarak, kendilerinde değerli bir taraf görmeden yapamadıkları, ama gerçekte böyle bir değer taşıyacak olgunluğa da henüz ulaşmadıkları bu yılların tehlikeli ölçüde kaygan ruhsal zemini üzerinden çekip götüren, bu kökü dışarıda çağrışımlar ve dişarıdan eğreti alınmış bu duygulardır. [...] İşte öğrencilerin ruhsal gelişimine yardım edecek böyle bir yanılsama, böyle bir düzen eksikti yatılı okullarda; her ne kadar okul kitaplığı klasik yazarların yapıtlarını bünyesinde barındırıyorsa da, bunlara sıkıcı şeyler gözüyle bakılıyor, geriye de kala kala aşırı duygusal anlatı ciltleriyle askerlik konularına ilişkin yavan mizah yazıları kaliyordu. (Musil 2014: 24-25)

Askeri eğitim mantalitesi, edebiyata karşı sporun ve hayvani mücadelenin saygınlığında ön plana çıkartılmaktadır. "Spor merakı" ve edebiyatın aksine "gimnazyumlarda" aşırı derecede vurgulanan "hayvansal uğraş" (Musil 2014: 26) gençleri yukarıda bahsi geçen duygu ve düşüncelerden alıkoyar.

Törless söz konusu uğraşlardan ikincisine yönelmeyecek kadar düşünsel tipte biriydi; okuldaki yaşamın insanı kavgalara ve yumruklaşmalara sürekli hazır olmaya zorlaması karşısında, başka yerlerden ödünç alınmış eğreti duyguların gülünçlügüünü pek ince ruhlu bir tavırla yansıtıyordu. Varlığı böylece belirsiz nitelik kazanıyor, onu kendi kendisine götüren yolu ele geçirmesine set çeken bir iç çaresizliğiyle karşı karşıya birakıyordu. (Musil 2014: 26-27)

Eserde her anlamda bir sınırlandırılmışlık söz konusudur. Buradaki "sınırlandırıcı darlık"1n, böyle bir askeri okuldaki eğitim ve ilkelerden meydana gelen "tinsel" bir darlığın yanında, "mekânsal” bir darlık olduğu da söylenebilir (Johann 2003: 271). 
Okulun mekânsal ve tinsel izolâsyonu, öğrencilerin diğer faaliyetler ve dikkat dağıtıcı unsurlar aracılığıyla iç baskıyı telafi edebilecekleri bir alan yaratmasına izin vermez. ${ }^{3}$ İnce ruhlu Törles, okul sınırları içinde "mucizemsi bir tekerlek gibi aralıksız yuvarlanıp" duran, çevresine "boyuna yeni, boyuna beklenmedik yaşantılar" (Musil 2014: 31) saçan bir hayatın tam tersine kendini yaşayan bir ölü gibi hisseder.

Törless, kafasında bu düşüncelerle göğüs geçirdi; kendisini okulun bunaltıcı havasına yaklaştıran her adımda, içinde bir şeylerin daha sıkı düğümlendiğini hissediyordu. [...] Sanki hoyrat bir bıçak darbesiyle kesip atar gibi, günün bitimini alabildiğine şaşmazlıkla belirleyen bu çan sesleri kadar onu ürküten bir başka şey yoktu. Çünkü alışılmışın dışında bir şey yaşadığı yoktu Törless'in; hayatı sürekli bir ilgisizlik içinde renksiz geçip gidiyordu; durum böyleyken üstelik çan sesleri yaşadığı hayatı alaya alınacak bir havayla donatıyor, onun kendi kendisine, kendi alınyazısına ve ölüp gitmiş güne ilişkin çaresizlik taşan bir hırsa kapılıp titremesine yol açıyordu. (Musil 2014: 31)

Hayattan bu şekilde koparılma, gençlerde farklı olumsuz gelişmelere yol açmaktadır. Böylece bu olumsuz gelişmeler, eylem sırasında "çeşitli sınırı aşma biçimlerine" neden olur, bunların "bazıları sadece yatılı okulun düzenini, bazıları da toplumun düzenini ilgilendirir" (Johann 2003: 79-80). Sürekli dar ve otoriter düzgülere maruz kalan gençler çeşitli sorunlar yaşayabilirler. Özellikle şiddet ve cinsellik ile ilgili sorunlar ortaya çıkar.

Gençlerin yaşadıkları sorunların çoğu sebebini, okulda verilen eğitimde ve eğitim ordusunun sözde neferleri olan öğretmenlerde aramak gerekir.Okuldaki eğitimin etkisizliği ve verimsizliği, romandaki öğretmenlerin imajına yansımaktadır. Öğretmenlerin yozlaşmış fizyonomisi, "belli bir ölçüdeki şaşkınlığa, esirgenmiş zevklerin atak bir yoldan ele geçirilişine, okulda erkeksi ve gözü pek bir davranış gözüyle" (Musil 2014: 196) bakan ve henüz yetişmekte olan öğrencilerle apaçık bir tezat oluşturmaktadır.

Çünkü o zaman ahlâk denen uyarıcı söz, dar omuzlarla, incecik bacaklar üzerinde sipsivri ileri firlamış göbeklerle ve sanki hayat huşu dolu bir iç rahatlığı sağlayan çiçeklerle bezenmiş bir kırdan başka bir şey değilmiş gibi gözlükler gerisinden koyunsu bir masumlukla ötede beride otlayan gözlerle gülünç bir ilişki içinde insanın karşısına çıkıyordu. (Musil 2014: 196)

Öğretmenlerin zihniyeti, mevcut iktidar lehine "sistemin içinde bulunan çoğaltma eylemlerine" dayanmaktadır ve bu nedenle "kendi mental ve sosyal durumlarını yaratıc1 bir şekilde sorgulamaktan" (Baur 1973: 38) yoksundurlar. Bu yüzden bu okuldaki öğrenciler hem "yaşamla ilgili" bilgilere, hem de "[...] hastalığa ve gülünçlük derecesine kadar varan bayağılığa ve şehvet düşkünlügünün o çeşitli aşamalarına ilişkin hiçbir sezgiye" (Musil 2014: 196) sahip olamazlar. Öğretmenler burada kendilerini “insanın iç dünyasına ilişkin fazla bilgileri” (Musil 2014: 232) olmayan kişiler olarak

\footnotetext{
${ }^{3}$ 19. yüzyılda yatılı okul, ideal bir eğitim biçimi olarak görülmekte ve şehir yaşamına olan uzaklık, yatılı okul eğitiminin bir avantajı olarak kabul edilmektedir. Bu düşünce Die Verwirrungen des Zöglings Törleß romanında açıç̧a belirtilmektedir: "Bayan Törless' in oğlunu böyle uzak ve sevimsiz bir kentte bırakıp gitmeye katlanmasının nedeni, burada Katoliklerin yönetiminde ünlü bir yatılı okulun bulunmasıydı; geçen yüzyılda bir vakıf arsası üzerine kurulan okul, yeni yetişen gençleri büyük kentlerin hayli zararlı etkilerinden korumak için başka bir tarafa taşınmayarak olduğu yerde bırakılmıştı" (Musil 2014: 16).
} 
sunarlar. $\mathrm{Bu}$ yetersiz ve kayıtsız tutum, matematik öğretmeninin Törless'in sorularını cevaplama noktasında kendini iyice hissettirir. Matematik öğretmeni, Törless'e anlaşılır bir cevap vermek yerine, "bilim otoritesinin arkasina" (Grossmann 1988: 94) saklanmaya çalışır. Otoriter bir ifade tarzı ile kendini haklı çıkarır ve böylece bu bilimi dokunulmaz ve kutsal olarak tanımlar (Baur 1973: 38). Törless'in soruyu sorgulaması yerine öncelikle kendisine inanmasını salık verir.

Sevgili evladım, inanacaksın böyle olduğuna, bitti; bir gün gelir, belki şimdikinden kat kat daha fazla anlarsın matematikten, o zaman nedenini öğrenirsin; ama şimdi yapacağın tek şey inanmaktır. "Çünkü işin içinden başka türlü çıkılacak gibi değildir, sevgili Törlessciğim; matematik başlı başına bir dünyadır ve onun gerektirdiği her şeyi sezebilmesi ve anlayabilmesi için insanın epey bir zaman bu dünyada yaşaması gerekir”. (Musil 2014: 134-135)

Öğretmenlerin eğitimci olarak yetersizliği ve yeteneksizliği, Basini olayının soruşturulmasında da ortaya çıkmaktadır. Yetişkin öğretmenler, elebaş Reiting tarafından manipule edilen öğrencilerin "parlak bir biçimde sahneye" (Musil 2014: 228) koyduğu sözde tiyatro aracılığıyla kolayca kandırılmaktadırlar. Törless okuldan kaçma nedenini ve düşüncelerini, soruşturma kurulunun karşısında açıklamaya çalıştığında, öğretmenler onun ince düşünülmüş, hatta bir o kadar da acı veren açıklamalarını sıkıcı ve anlaşılmaz bulurlar. Ancak bu sıkıcılık ve anlaşılmazlık, okuldaki öğretmenlerin hem sabırdan hem de öğrencileri anlama ve empati kurma becerilerinden yoksun olduklarını göstermektedir. "Okul sisteminin patronu" (Tezcan 2017: 412) olan müdür, soruşturma esnasında Törless'in eza veren felsefi bilgilerinden bunalır ve Basini'yle ilgili hadisenin sonucuna dair bir ipucu vermesini bekler, çünkü artık dayanacak sabrı kalmamıştır: "Törless en sonunda bir evet dese ve hakkında bir yargıya varılabilmesi için sağlam bir zemin ortaya çıksa, kendisi de sevinecekti; ama 'Hayır. Böyle bir şey söz konusu olmadı benim için,' diye yanıtladı soruyu” (Musil 2014: 232).

Müdürün geleneksel normlarla sınırlı olan duygu ve düşünceleri, öğrencisini dinlemesine izin vermez. Burada söz konusu olan, Törless'in "eksik olan anlaş1labilirliği” değil, aksine öğretmenlerin "sınırlı bilinç ufku”dur (Grossmann 1988: 51). Bu, müdürün ve sisteminin, öğrenci olan hassas ve boyun eğmez düşünürlere karş1 ikiyüzlüleri tercih ettiğini açıcça göstermektedir. ${ }^{4}$ Müdüre göre Törless gibi bir öğrenci, öğretmenleri üzerinde baskı oluşturur ve bütünleşmeyi sağlayan başarılı sosyalleşme normlarını tehdit eder.

\footnotetext{
“Bu Törless'in kafasının içinde neler var, bilmem. Ancak şurası kesin, ruhsal bakımdan aşırı bir gerilim içinde bulunuyor; dolayısıyla, bir yatılı okul onun kalması için uygun yer değil artık. Bundan böyle alacağı manevi besinin büyük bir titizlikle denetim altında tutulması gerekiyor, bu kadarını da bizim burada gerçekleştirme olanağı yok. Bu yolda bir sorumluluğu daha çok üzerimizde taşıyabileceğimizi sanmıyorum. Törless özel bir eğitim görmeli; bunu bir mektupla babasına bildireceğim.” Odadakilerin hepsi de,
}

\footnotetext{
${ }^{4}$ Burada Hermann Hesse'nin yine eğitim sisteminden acı çeken bir gencin hikâyesini anlatan "Unterm Rad" (Çarklar Arasında) romanının şu meşhur satırları akıllara getirilebilir: "Sınıfında bir dahi görmektense birkaç eşek görmek daha çok memnun eder bir öğretmeni. Aslında bu tutumda da haksız sayılmaz, ne de olsa görevi olağandışı ve acayip kişileri değil, iyi Latince ve matematik bilen dürüst ve efendi orta sınıf insanını yetiştirmektir” (Hesse 2018: 116).
} 
içtenlikle müdürün bu önerisini olumlu bulduklarını hiç vakit geçirmeden belirttiler.

(Musil 2014: 237)

Musil, burada müdürü ve öğretmenleri okulda sadece görevlerini yerine getiren duygusuz insanlar olarak betimler. Tüm öğretmenler, Törless'in geleceğine karar veren okul müdürünün keskin kararını tereddüt etmeden kabul ederler. Roman yazarı, Törless nezdinde öğrencilerin okul otoritesine karşı güçsüz ve çaresiz olduklarını vurgular.

\section{Hitler Ekolünün Doğuşu ${ }^{5}$}

Popüler asker - okul - hikâyeleri açısından Die Verwirrungen des Zöglings Törless eserinde sadece askeri okul sistemindeki eğitim ve öğretim üzerinde durulmaz, ayrıca onun sosyo-kültürel yansımaları da açıklığa kavuşturulur. Musil, ilk deneyimi olan bu eserde sadece "askeri bir okulun inzivasındaki bazı gençlerin psikolojik gerilimlerini ve cinsel saldırılarını" (Berghahn 1963: 28) ele almakla kalmaz, aynı zamanda toplum ve kurumlarıyla da bağlantı kurar. Sadistliğe ve kurbanın (Basini’nin) cisimleştirilmesine dikkat çeker. Bu nedenle Basini'nin romandaki cinsel istismarını ve insanlık dışı küçük düşürülüşünü, sadece kural olarak benimsenmiş düzgülerden gençlik sapması olarak görmek, çok fazla tek taraflılık olur. Bu roman, zamanın çelişkili ruhuna yansıyan çeşitli sosyo-kültürel ve siyasi yönleri gün ışı̆̆ına çıkarmaktadır.

$\mathrm{Bu}$ bağlamda güç ve şiddet, romanın yazıldığı dönemin öne çıkan yanlarındandır. Romandaki "böyle yatılı okulun her sınıfı kendi başına bir devlet sayılırdı" (Musil 2014: 73) cümlesiyle sınıf, yetişkinlerin baskısı altında olan bireylerin bir toplamı olarak değil, Reiting ve Beineberg önderliğinde kendi hiyerarşisine ve davranış kurallarına göre hareket eden, bireyi ciddi bir şekilde kısıtlayan, okulla ilgili baskıcı direktiflerden ve normlardan uzakta olan küçük bir devlet olarak görülmektedir. Bu sınıf, "bir grubun diktatörlüğünün tasviri” (Baur 1973: 39) olarak işlev görmektedir.

Sınıfın diktatör ruhlu karakterlerine bakıldığında, Musil, cinsellik üzerinden güç ve şiddete dayalı bir yapılanma oluşturur. Okul romanlarının olağan şemasının aksine, bu romanda problemler eğitimciler tarafından değil, sınırları dar olan okuldaki öğrenciler tarafından yaratılır. Burada sadece yatılı okul şakaları, ergenliğe dair bunalımlar ve çok bahsi geçmeyen homoseksüel ilişkiler değil, aynı zamanda sadistlik, yani amaçsızca işkence çektirilen zayıfları simgeleyen kurbanın seçimi de söz konusudur. Dolayısıyla eserde, edebiyata yansıyan sosyal güç dengelerinin bir görüntüsü de mevcuttur.

Romanda geçen meşhur kan kırmızısı oda, ilk önce üç ana karakterin, yani Törless, Reiting ve Beineberg'in "sığınma yeri olarak", daha sonra Basini için "işkence odas1 olarak" (Berghahn 1963: 30) görev yapar. Bu oda, "kamu ahlakının ve

\footnotetext{
${ }^{5}$ Ekol, "bir bilim ve sanat kolunda ayrı nitelik ve özellikleri bulunan yöntem veya akım, okul” (Tdk) demektir. Hitler bilhassa çok değer verdiği eğitim üzerinden kendine has bir ekol (Schule) yaratmak ister. $\mathrm{Bu}$ manada gençlik, Hitler için bambaşka bir öneme sahiptir. Dolayısıyla Nasyonal Sosyalist eğitim politikası için, "Wer die Jugend hat, hat die Zukunft" (Stucki 2002: 1) (Gençliğe sahip olan, geleceğe sahip olur) mottosu bu önemi doğrulamaktadır.
} 
normlarının bir temsilcisi" olan okul çatısı altında bulunmaktadır (Baur 1973: 33). Aslında bu çatı katı, gizlice izole edilmiş ve tehlikeli bir şekilde çarpıtılmış kuralların kör bir noktası olarak ortaya çıkmaktadır. $\mathrm{Bu}$ yerin tasviri zaten eylem sırasında geliştirilecek anormalliği ve barbarlığg göstermektedir.

Duvarlar, [...] kan kırmızısı bayrak beziyle baştan aşağı kaplanmış, [...] Ama bu gizlilik, bu alarm sicimleri, aşırı bir direniş ve bir mahremiyet havası yaratması istenen bu revolver gülünç görünüyordu gözüne. Bir haydut hayatı yaşadıklarına kendi kendilerine inandirmak ister gibiydiler. (Musil 2014: 69-70)

Sınıfın bir nevi diktatörü olan Reiting ve Beineberg, bu dar çatı katında entrikalar çevirip şahısları yargılar ve cezalandırırlar. Törless, gizli "genelkurmay başkanı" (Musil 2014: 73) kimliğiyle rolünü yerine getirir. Törless, "daha kıvrak bir zekaya" (Musil 2014: 73) sahip olduğu için Reiting ve Beineberg'e ișe yarayacak tavsiyelerde bulunur ve "gerektikçe onların koruyucu kanatları" (Musil 2014: 73) altında olmanın zevkini çıkarır. Bu açıdan Törless, toplumdaki iktidar sahiplerinin teveccühünü ya da koruması altındaki entelektüeli temsil eder. Dolayısıyla tam anlamıyla söylemek gerekirse, bu dostluk "herkesin rolünü üstlendiği ve kendi hedeflerinin peşine düştüğü bir ittifak" (Grossmann 1988: 58) olarak nitelendirilebilir. Bireylerin güç dürtüsüyle kontrol edildiği, küçük bir devlet olan bu sinıfta, zayıf ve yetenekleri az olan sinıf arkadaşlarının kendilerine karşı gelmeleri imkansızdır. Sınıfa hakim olan bu üç kişi, Basini üzerindeki güçlerini daha egemence kullanırlar.

Otoriter güç sahipleri Reiting ve Beineberg tamamen farklı özelliklere sahiptirler. Reiting "makyevelizm ${ }^{6}$ tarzında bir iktidar hırsına", Beineberg ise bazen bir çatışma faktörü olarak, ama daha çok tamamlayıcı bir etken olarak ortaya çıkan ve sınıfı tiranlaştırmaya yarayan "usdışı spekülasyonlara" sahiptir (Arntzen 1980: 99). Reiting "kendisine karşı koyana hiç aman vermeyen acımasız oğlanın biri”dir (Musil 2014: 72), ancak dünyadan bihaber ve bilgisiz bir otoriter kişi değildir, aksine kitle ruhundan çok iyi anlayan modern bir diktatördür. Kitleleri kendi yararına kullanmak için onların karakteristik ve ahlaki kusurlarını, ayrıca dezavantajlı ve insani özelliklerini öğrenip onlar üzerinden yürümeyi alışkanlık haline getirmiştir. Kitleleri yönetir, kitleler tarafindan bir yerlere getirilir ve daha sonra acımasızca onlara tahakküm eder. Modern anlamda diktatörlüğün doğuşu ve amac1, Reiting figüründe görülebilir.

Onun da [...] herkesten saklı köşe bucakları vardı ve buralarda herkesten gizli tuttuğu günlüğünü saklamaktaydı. Bu günlük geleceğe ilişkin olarak en atak tasarılarını ve arkadaşlar arasında çevirdiği yığınla entrikanın nedenlerini, bunların sahneye konuluşunu ve nasıl bir seyir izlediğini bir bir içermekteydi. Çünkü Reiting'in en zevk aldığı şey, arkadaşları birbirine düşürmek, bir arkadaşını ötekinin yardımıyla sindirmek, onu bunu zorla kendisine yaltaklanmaya ve yaranmaya zorlamak, arka planda hala bir

\footnotetext{
${ }^{6}$ İtalyan devet adamı ve düşünür Niccolò “Machiavelli'nin siyaset ve ahlâk anlayışı arasındaki ilişkiye kendi zamanına genel olarak hâkim olan geleneğin dışında yeni bir bakış açısı getirmiş olmasıyla ilgili olarak ortaya çıkmış siyasî bir yorum ve eylem tarzının genel adıdır. [...] Makyavelizm denince akla gelen ilk şey, 'amaç' (elbette siyasî olan) her ne olursa olsun onu gerçekleştirmek için bütün araçların kullanımını meşru sayan bakış açısıdır” (Kesgin 2015: 106-107).
} 
kin ve direnişin varlığı sezilen bu yaltaklanma ve yaranmalarla gönlünü eğlendirmekti.

(Musil 2014: 70-71)

Reiting'in izlediği bu yol sayesinde çoğu insan hep onun yanında yer alır. Bu konuda yeteneklidir ve bunlarla pratik yaparak geleceğine yatırım yapar. Beineberg, Reiting'in kafasında olan düşüncelerini eleştirel bir tarzda şu şekilde dile getirir:

[...] bir insanı düpedüz avcunun içine almanın ve dolayısıyla insana bir araç gibi davranma konusunda antreman yapabilmenin onun için de ayrı bir değeri vardır. $\mathrm{O}$ hükmetmek isteyen biridir; [...] Reiting, Basini'yi kurban edebilir, sırf bir merak duygusundan yapabilir bunu. Ahlak açısından onu parça parça doğrayabilir ve bunu yaparken tek amacı, böylesi işlere yeltenebilecek kimsenin nelerle karşılaşacağını görüp öğrenmek olabilir. (Musil 2014: 103-104)

Reiting'in iki karakteristik özelliği vardır. Bunlardan ilki, hedefine ulaşabileceği insanların onurunu ve gururunu acımasızca hiçe saymak, diğeri ise Törless'in bile "Reiting'in dimdik ve kıvrak yürüyüşünde" hissettiği, görünürdeki o "masumluk ve sevimlilik"tir (Musil 2014: 118). Reiting "kendi soyunu asilleştirmeye ve efsaneleştirmeye” (Johann 2003: 300) çalışır. Bunu yaparken doğal üstünlüğünü hissettirir ve kendini kahramanlaştırmaya çalışır.

Reiting, babasının tuhaf bir tedirginlik içinde yerinde duramayan ve günlerden bir gün kayıplara karışıp bir daha kendisinden haber alınamayan bir adam olduğunu anlatmaya bayılıyordu. Dediğine bakılırsa, babasının adı, çok soylu bir ailenin kullandığı takma addan başka bir şey değildi, ileride ise annesinin aracılığıyla büyük tutku ve hedeflerle tanışacağını umuyordu. Hükümet darbeleri tasarlıyor, büyük çapta politik bir yaşam düşlüyor, bunun için de ileride subay olmayı gönlünden geçiriyordu. (Musil 2014: 7172)

Görüldüğü gibi Reiting'in insanlık dışı davranışı, "sevimsiz denemeyecek bir gülüş" (Musil 2014: 71) tarzındaki maskenin arkasına gizlenmiştir ve ayrıca bu gülüş, kendi yararına göre dostça ya da düşmanca tavır alan bir zorbanın ikiyüzlülügüünü simgelemektedir.

Bir diğer diktatör Beineberg'in durumu ise daha karışıktır. O, babasının etkisi ile gelişen Hint mistisizmine yoğunlaşır. Babası, Hindistan'da İngilizlerin hizmetinde genç bir subay olarak çalışırken "Budizm'e özgü gizemli ve acayip meditasyon havasından da biraz bir şeyler sezinler gibi olmuş ve bu sezinlemelerini bir daha elden çıkarmamaya" (Musil 2014: 35) çalışmıştır. Beineberg, Törless'in felsefi anlamda tartışabileceği tek arkadaşıdır. Ancak daha yakından bakıldığında Beineberg'in görüşleri sadece mistik ve usdışıcılık (irrasyonalizm) anlamında spekülasyon olarak ortaya çıkmaktadır.

Ernst Fischer'e göre, Beineberg'in “zulmü, insanları sonuna kadar aşağılama arzusu", "usdışıcılık felsefesinde, aklı ve insanlığı yok eden bir mistisizmde" dayanak bulur (Kroemer 2004: 99). Beineberg'de "Reiting'in sevimliliği ve karşısındakinin gönlünü kazanma becerisi" (Musil 2014: 72) yoktur. Aksine insana rahatsılık ve güvensizlik veren bir duyguyu tetikleyen diş görünüşe sahiptir. "Beineberg'in halindeki serinkanlılık, o fillozofça hava hemen bütün arkadaşlarda bir güvensizliğe yol açıyor, varlığının temelinde birtakım çirkin aşırılıkların saklı yattığı izlenimini uyandırıyordu" (Musil 2014: 72). Anlatıc1, bu izlenimini Törless'in gözünden birçok yerde ifade eder. 
Beineberg, çirkin ve tuhaf bir görünüme sahiptir, örnek olarak; "baş tümüyle bir yarasa başı izlenimi” (Musil 2014: 38) vermekte, “acayip bir puta” (Musil 2014: 86) benzemektedir, "ördüğü ağda pusuya yatmış sessizce bekleyen kocaman ve dehşet verici bir örümcek" (Musil 2014: 100) gibidir. Beineberg'in bu mecazi tasviri, onun olumsuz ve tehlikeli doğasını göstermektedir. Bu doğası, ayrıca Beineberg'in zekâsına ve iktidar hırsına rağmen "bir iki yıl önce [...] savaş"ta (Musil 2014: 72) rakibi Reiting'e karşı yenilgisinin bir nedenidir. Ancak daha sonra ikisi yekvücut olurlar. Reiting, Basini'nin hırsızlığını ortaya çıkarıp onu kendi arzularını ve zevklerini tatmin etmek için köleleştirir ve ona kötü davranırken, Beineberg, usdışı ve mistik felsefesi nedeniyle Basini'ye işkence edip onu suistimal etmeye, hatta bir nesne gibi onun üzerinden deney yapmaya çalışır. Beineberg üstelik yaptığı işkenceyi saçma spekülasyonlarla haklı çıkarmaya çalışır ve bunu kendisi için bir görev olarak görmeye başlar:

Hani Basini'ye işkence etmenin, diyeceğim onu aşağılamanın, burnunu sürtmenin, kendimden uzak tutmamın bana güç gelmesi hiç de olumsuz bir şey değildir. $\mathrm{Bu}$ iş, bir kurban istemek demektir. Pislikleri silip götürecek bir kurban. Yalnızca insan olmanın hiçbir anlam taşımayıp öykünme ürünü bir dış benzerlikten öteye geçmediğini her gün Basini üzerinde öğrenmeyi, kendime karşı yerine getirmem gereken bir ödev sayıyorum. (Musil 2014: 106)

Törless, Beineberg'in Hint mistisizmine dayalı spekülasyonlarını yanlış bulur. Beineberg'in Basini üzerinde kendine bir görev olarak atfettiği tavrı, onun saçma ideolojisine bağlı fanatik bir inançtan başka bir şey değildir (Reis 1983: 42). Ayrıca Beineberg'in kendini saçma ve mistik düşünceler üzerine haklı çıkarma girişiminde bulunmas1, bize Nasyonal Sosyalistlerin savunduğu propagandayı ve siyaseti hatırlatmaktadır.

Bu bağlamda iki diktatör Reiting ve Beineberg arasındaki güç dengesi, eski Roma tanrısı Janus'un ${ }^{7}$ ikiyüzlülüğüne benzetilebilir, çünkü "Beineberg kurbanlarının ruhunu, deyim yerindeyse psikolojisini araştırıp onlar üzerinde güç kullanmayı isterken, Reiting dışarıyı, adeta siyaseti hedef alır" (Johann 2003: 303). Ayrıca zor kullanarak kontrol altına alınanların yok edilmesi (Willemsen 1985: 42) anlamında şiddete başvuran güç, "askeri genel ilkeleri” (Mix 1995: 135) yansitır. Buradaki fiziksel şiddet, gücün kullanılması ve uygulanması için en önemli araç olarak işlev görür. Buradan da özellikle erk sahiplerinin elindeki gücün ve nüfuzun genel şeması, dolayısıyla diktatörlüklerin doğuşunun ve amacının bir sınıfın içindeki ilişkilere dayanarak yansitıldı̆̆ı söylenebilir.

Dönemin teşhisi olarak, Musil günlüğüne şöyle yazar: Reiting ve Beineberg: "Günümüzün diktatör ruhlu kişileri. Yığın onların gözünde baskıyla ikna edilecek bireylerden oluşuyor" (Musil 2018: 296). Musil'in siyasetle ilişkili bu yorumu Die

\footnotetext{
7 “Roma'nın mitolojik tanrısı Janus (Ianus) [...] devleti simgeler. İki çehreli (yüz) olarak betimlenir. Yüzün biri sağa, biri sola bakar. Biri geçmişin sahipliğini, diğeri geleceğin güvencesini anlatır. Gene Tanrı Janus'un bir yüzü, ülkenin bayındırlığını, uygarlığını anlatır, diğeri de bunların nasıl korunacağını bildirir" (Coşturoğlu 1992: 188).
} 
Verwirrungen des Zöglings Törleß romanının siyasi ve sosyo-kültürel yönlerini açığa vurmaktadır. Kitle hareketi düzeneği, dışadönük bir karakter olan Reiting tarafından dile getirilmektedir.

Zaten ben toplu eylemleri severim. Hani kimsenin pek fazla bir katkıda bulunmasi gerekmez; öyleyken dalgalar giderek yükselir, yükselir, sonunda ne kadar baş varsa hepsinin üzerinde kavuşur, [...] kimse serçe parmağını oynatmayacak, ama yine de müthiş bir firtına kopacaktır. (Musil 2014: 198)

Eserde bu düşüncelerin eyleme dökülmüş halini görmek son derece normaldir. Basini tüm yaşananlara rağmen artık Reiting ve Beineberg'e itaat etmek istemediğinde, Reitig, Basini'yi sınıfa teslim etmeye karar verir, çünkü insanları birbirine karşı kışkırtmak ve kalabalığı manipüle etmek onun için "bulunmaz bir zevktir” (Musil 2014: 198). Basini sınıfa teslim edildiğinde öfke, nefret, küçümseme hepsi birbirine karışır ve kitle psikolojisi teşekkül eder. ${ }^{8}$

\begin{abstract}
Kapılar kapatılıp gereken yerlere gözcüler yerleştirildikten sonra, Basini'nin giysilerinden soyunması herkesi eğlendirdi. Reiting, annesinin Basini’ye yazdığı bir deste mektup tutuyordu elinde; derken bunları okumaya koyuldu: [...] Çirkin gülüşmeler, ölçü tanımayan alaylı sözler kalabalık içinden yükseldi. Reiting okumasını sürdürmek istiyordu ki ansızın biri itti Basini’yi. Basini'nin üzerine yıkıldığı bir başkası yarı şaka, yarı kızmış onu tutup geri itti. Bir üçüncüsü onu alıp daha ileriye aktardı. Ve Basini göz açıp kapamadan ağzı korkudan sonuna kadar açık, firıl firıl dönen bir top gibi gülüş̧eşler arasında çırılçıplak oradan oraya savrulmaya başladı. Yaşa, varol bağrışmaları, sınıfın dört bir yanından Basini’ye uzanan eller, bir yerden bir yere fırlatılan bir vücut, sıraların keskin köşelerine çarparak yaralanmalar, bir ara diz üstü düşüş, incinen ve kanayan diz kapağı, sonunda al kan içinde toz toprağa bulanmış; bakışlarında hayvansı bir ifade, camsı gözleriyle yere yığılıp kalmıştı Basini. Ansızın baş gösteren sessizlikte; herkes onun yere serilmiş yatışını görmek için ileri atıldı. (Musil 2014: 223-224)
\end{abstract}

Gençlik dönemlerindeki barbarlıkta "insanın insanlık dışı olan şeye sapkınlığı" (Jens 1989: 62) ve "toplama kamplarının metodolojisi” (Berghahn 1963: 29) belirgindir. Bu barbarlığın sıradan öğrenci budalalıklarının ve yatılı okuldaki ruhsal bozukluklarının altında meydana geldiğini söylesek yanılmış olmayız. Askeri bir öğrenci olan Fritz von Unruh, askeri okulun "gelecekteki toplama kamplarının ana modeli” (Von Unruh: 1948: 22) olacağına dikkat çeker. Ancak tam bir benzetme yapmak doğru mudur, bilinmez. Yine de "toplama kamplarının dehşeti" ve "insanları tamamen parçalayan bir gücün sapkın zevki” (Fischer 1991: 246) bu askeri eğitim kurumlarının güç dengelerinde tam olarak doğrulanan şeylerdir. Bunun için de toplama kamplarının metodolojisinin, gençlik zulümlerinde ortaya çıktığı söylenebilir.

\footnotetext{
8 “İnsanlar mesafe yüklerinden ancak hep birlikte kurtulabilirler; kitle içinde olan da işte budur. Deşarj sırasında ayrımlar bir kenara atılır ve herkes kendini diğerleriyle eşit hisseder. Arada neredeyse hiçbir uzamın kalmadığı o yoğunluk içinde, vücut vücuda abanır, her bir insan diğerine kendisine olduğu kadar yakındır; sınırsız bir rahatlama hissi ortaya çıkar. İşte, insanlar hiç kimsenin diğerinden daha üstün ya da iyi olmadığı bu mutlu an uğruna bir kitle oluştururlar” (Canetti 2010: 19).
} 
Musil, Nazi Almanya'sının filizlenen temellerini zaten Die Verwirrungen des Zöglings Törleß eserinde, yani sadist askeri öğrenci Beineberg karakterinde gösterdiğini dile getirir: "Darbeci bir subayın günü geldiğinde dünyanın önderlerinden biri olacağı aklımıza gelir miydi? Boineburg [Beineberg] bunu sezmişti” (Musil 2018: 188). Musil, faşist ideolojinin Hitler öncesi dönemde yayılmaya başladığını ve bu yayılmanın kötü niyetli bir hale dönüştüğünü öngörmüştür (Kesser 1960: 184). Bu roman, yazarın kendi eseri hakkındaki yorumlarına dayanarak, Hitler diktatörlügünün ve soykırımının bir kehaneti olarak düşünülmektedir (Musil 1981: 1417).

\section{Sonuç}

Avusturya edebiyatının yetiştirdiği en müstesna değerlerden biri olan Robert Musil, Die Verwirrungen des Zöglings Törle $\beta$ adlı romanında 20. yüzyılın başındaki Viyana modernizmiyle birlikte gelen toplumsal değişikliklere 1şık tutmuştur. Bunları, genç kitle üzerinden eserine yansıtmıştır.

Eser, çeşitli konuları içerse de, biz çalışmamızda 20. yüzyıl başındaki hadiselerin eğitime yansımasına ve faşizmin eğitim üzerinden gelişip olgunlaşmasına odaklandık. Eserde ele alınan eğitim, tam anlamıyla genç beyinleri, askeri bir zihniyette yetiştirme üzerine kurulmuştur. Romandaki askeri okul, sınıf farkının ön plana çıktığı, seçkin sınıfa ait çocuklarının kabul edildiği ve bu çocukların gelecekte iş sorunu çekmeyeceği sözde eğitim kurumudur. Buradaki cansız, mekanik, katı ve otoriter eğitim, sanat ruhu taşıyan küçük beden(ler)e ağır gelmiştir. Okulda bilimin yerini vahşi ve uygunsuz olan hayvani davranışlar almıştır. Bu eğitim tarzı, kimi için -Reiting ve Beineberghedeflenen yolda atılan güçlü bir adımken, kimi için - Törless - günden güne yok olma sebebidir.

Romanda eğitim sorunlarının yanı sıra dönemin ruhuna yansıyan sosyo-kültürel ve siyasi meseleler de zuhur etmektedir. Çalışmamızda ele aldığımız eğitim sorunsalı, siyasi anlamda karşılığını bulmaktadır. Zira bu eğitim, gençler üzerinden geleceği tesis edecek adımlar üzerine kurulmuştur. Bunları da Reting ve Beineberg karakterlerinde görmek mümkündür. $\mathrm{Bu}$ iki figür nezdinde, modern anlamda diktatörlüğün doğuşu ve toplama kamplarının metodolojisi gözler önüne serilmiştir. Bu bağlamda eğitim, tek başına ele alınıp değerlendirilebilecek bir olgu değildir. Bir toplumda uygulanan eğitim sistemi ve yerleştirilmeye çalışılan zihniyet, bir diğer tabirle eğitim politikası, o toplumu yönetenlerin ya da erk sahiplerinin ideolojisini yansıtır, dolayısıyla toplumsal bir kurum olan eğitimi, toplumun diğer kurumlarıyla birlikte değerlendirmek gerekir.

\section{Kaynakça}

Birincil Kaynaklar

Musil, Robert (2014): Öğrenci Törless'in Bunalımlarl, (Çev: Kamurân Şipal), 2. Baskı, İstanbul: Alakarga Sanat Yayınları. 


\section{İkincil Kaynaklar}

Arntzen, Helmut (1980): Musil-Kommentar. Sämtlicher zu Lebzeiten erschienener Schriften außer dem Roman „Der Mann ohne Eigenschaften“, München: Winkler Verlag.

Asutay, Hikmet (2020): Gençlik Edebiyatı: Ergen Roman, 3. Bask1, İstanbul: Paradigma Akademi.

Aytaç, Gürsel (2005): Çă̆daş Alman Edebiyatı, 5. Baskı, Ankara: Babil Yayıncılık.

Baur, Uwe (1973): Zeit- und Gesellschaftskritik in Robert Musils Roman Die Verwirrungen des Zöglings Törleß, In: Uwe Baur, Dietmar Goltschnigg (Hg.): Vom Törleß zum Mann ohne Eigenschaften, München/Salzburg: W. Fink, 19-45.

Berghahn, Wilfried (1963): Robert Musil in Selbstzeugnissen und Bilddokumenten, Reinbek bei Hamburg: Rowohlt Verlag.

Canetti, Elias (2010): Kitle ve İktidar, (Çev: Gülşat Aygen), 4. Basım, İstanbul: Ayrıntı Yayınları.

Coşturoğlu, Mustafa (1992): Toplumsal Çözülme (Toplumsal Patoloji), Ankara: Gündoğan Yayınları.

Fischer, Ernst (1991): Von Grillparzer zu Kafka. Von Canetti zu Fried. Essays zur österreichischen Literatur. Frankfurt a. M.: Vervuert Verlag.

Grossmann, Bernhard (1988): Robert Musil. Die Verwirrungen des Zöglings Törless, München: Oldenbourg Verlag.

Hesse, Hermann (2018): Çarklar Arasında, (Çev: Kamuran Şipal), 10. Baskı, İstanbul: Can Yayınları.

Issler, Maria (1972): Robert Musil „Die Verwirrungen des Zöglings Törless“: Versuch einer Interpretation, Zürich: Aku-Fotodruck Verlag.

Jens, Walter (1989): Sadistische Spiele auf dem Dachboden, In: Marcel Reich Ranicki (Hg.): Romane von gestern-heute gelesen. Bd. I. 1900-1918, Frankfurt/Main: S. Fischer, 55-63.

Johann, Klaus (2003): Grenze und Halt: Der Einzelne im „Haus der Regeln“. Zur deutschsprachigeInternatsliteratur, Heidelberg: Winter Verlag.

Kesgin, Ahmet (2015): Machiavelli ve Makyevelizm. Beytulhikme An International Journal of Philosophy, 5 (1), 105-139.

Kesser, Armin (1960): Begegnung mit Robert Musil. Gespräche und Aufzeichnungen, In: Karl Dinklage (Hg.): Robert Musil. Leben, Werk, Wirkung, Reinbek bei Hamburg: Rowohlt Verlag, 183-186.

Kroemer, Roland (2004): Ein endloser Knoten? Robert Musils Verwirrungen des Zöglings Törless im Spiegel soziologischer, psychoanalytischer und philosophischer Diskurse, München: Wilhelm Fink Verlag.

Minder, Robert (1962): Kadettenhaus, Gruppendynamik und Stilwandel von Wildenbruch bis Rilke und Musil. In: Robert Minder (Hg.) Kultur und Literatur in Deutschland und FrankreichFünf Essays. Frankfurt a. M.: Insel Verlag, 73-93.

Mix, York-Gothart (1995): Die Schulen der Nation: Bildungskritik in der Literatur der frühen Moderne, Stuttgart: Metzler Verlag

Musil, Robert (2018): Robert Musil: Günlükler, (Çev. Ahmet Arpad), 1. Basım,İstanbul: Everest Yayınlar1.

Musil, Robert (1981): Brief an Robert Lejeune, In: Adolf Frisé, u.a (Hg.) Robert Musil: Briefe 19011942, Reinbek bei Hamburg: Rowohlt Verlag.

Reis, Gilbert (1983): Musils Frage nach der Wirklichkeit, Königstein/Taunus: Anton Hain Verlag. 
Steinlein, Rüdiger (2013): “Kadettenliteratur” als jügendliterarisches Genre vom Wilhelminismus bis zum Nationalsozialismus, In: Richard Faber (Hg.), Totale Institutionen? Kadettenanstalten, Klosterschulen und Landerziehungsheime in Schöner Literatur. Würzburg: Königshausen\& Neumann Verlag, 109-133.

Stucki, Regula (2002): Wer die Jugend hat, hat die Zukunft, Berlin: Diplomica Verlag.

Tdk: https://sozluk.gov.tr/ (Erişim tarihi: 25.12.2020).

Tezcan, Mahmut (2017): Eğitim Sosyolojisi, 17. Baskı, Ankara: Anı Yayıncılık.

Tiefenbacher, Herbert (1982): Textstrukturen des Entwicklungs- und Bildungsromans: zur Handlungsund Erzählstruktur ausgewählter Romane zwischen Naturalismus und Erstem Weltkrieg, Königstein/ Taunus: Forum Academicum in der Verlagsgruppe Athenäum, Hain, Scriptor, Hanstein.

Von Unruh, Fritz (1948): Rede an die Deutschen, Frankfurt: Verlag der Frankfurter Hefte.

Willemsen, Roger (1985): Robert Musil: Vom intellektuellen Eros, München: Piper Verlag. 